\title{
IoT Based Gas Detection in Home Environment
}

\author{
Hema R, Subbulakshmi. K, Arulselvi S.
}

\begin{abstract}
The Hydro chlorofluorocarbon(HCFC) and Chlorofluorocarbon $(\mathrm{CFC})$ causes ozone layer depletion and pollutes the atmosphere. The usage of LPG without precautions creates fire accidents. The CFC released by air conditioners and refrigerator cause health issues. To solve these health problems and for safety purpose, this paper proposes for monitoring system to realize in indoor environmental pollutants. This system consists of ARM LPC 2148 microcontroller, a sensor module (mq-5 \& mq-135) and a Wireless Fidelity (WIFI) for communication. The data acquisition, monitoring and alarm are achieved by the proposed system. The experiments results reveal that data acquisition and transmission is reliable. Furthermore, new sensors can be integrated and an application can be developed to monitor the events in home environment.
\end{abstract}

Keywords : HCFC, CFC, LPG, Air Conditioner, Refrigerator, ARM LPC 2148, mq-5, mq-135, WIFI.

\section{INTRODUCTION}

The chlorofluorocarbon gas affects the ozone layer, and cause many environmental changes which eventually lead to the phenomenon of Global warming. This gas is mostly used in the air-conditioners and the refrigerators for cooling purpose. The techniques used in the refrigerators and air-conditioners, keep the internal environment cooled but towards the outer environment heat is emanated which cause the Greenhouse Effect too. 1976, the UNEP (United and Nation Environment Programmer) council discussed about the ozone layer damage. Subsequently, UNEP and WMO (World Metrological Organization) establish the Ozone Layer Coordination Committee (CCOL) to regularly assess the damage of ozone layer [1]. The CCOL decided to control the manufacture of Air-conditioners and Refrigerators and to scientifically observe the level of pollutants emanated from these equipments are within the accepted limit. Also, in 1997, the United Nations launched the "United Nations Framework convention on climate Kyoto Protocol" which states that the ratified state parties should reduce the level of greenhouse gas emissions.[1-10]

Apart from the environment damage these pollutants cause, they are also responsible for the development of some health issues, especially Chronic Obstructive Pulmonary Diseases. It has been discovered that if CFC gas level is increased in a closed room it will cause breathing difficulties. The WHO (World Health Organization) have also substantiated that vast majority of children develop breathing problems because of

\section{Revised Manuscript Received on August 22, 2019}

Hema $\mathbf{R}$ Assistant Professor,Department of Electronics And Communication Engineering,, Bharath Institute of Higher Education and Research, Chennai, India hemrbujradha@gmail.com

Subbulakshmi.K, Assistant Professor,Department of Electronics And Communication Engineering,, Bharath Institute of Higher Education and Research, Chennai, Indiap.sudha50@gmail.com

Arulselvi S.., Assistant Professor,Department of Electronics And Communication Engineering,, Bharath Institute of Higher Education and Research, Chennai, India. arulselvi2003@gmail.com these pollutants. Nowadays, the LPG (Liquid Petroleum Gas) is used in cooking stoves for household cooking. In this busy world there is possibility that some people forgot to turnoff the stove or an accidental leakage of gas can occur. The gas spread over the room can bring forth fire accidents or breathing problems for children, old-aged or disabled persons. Here the utility of IoT (Internet of Things) comes up. IoT is an ever growing network by which human race can control the physical objects through internet by enabling a communication between these objects/home appliances and the system. An IP address is allocated to these appliances. In short, IoT can be connected to devices like security system, in vehicles, electrical appliances in household, consumer goods, utility components, sensors, industrial and other everyday objects. The connected systems collect the information and transfer the data to the cloud where it can be stored and accessed by another user. This information can be stored accessed via Android, iOS or Webpage from anywhere in the world thereby enabling the human beings to control the level of indoor chemical pollutants at his fingertips.

\section{METHODS AND SYSTEM DESIGN}

The system is based on the new MINI ARM 7 Microcontroller LPC 2148 board for faster and reliable outcome. The Microcontroller normally repeat the process until the power supply is off once the microcontroller is fully programmed. By the help of the RS232 series programming of microcontroller Lpc 2148 ports is enabled for UART0 and UART1 communicate between pc and microcontroller board. In every Ten seconds the microcontroller sends the information data to the received from the sensor pin will transfer to Iot modem to store in serve or cloud and viewed in graph through Internet with allocated username Id and passwords. The ESP 01 is running at $80 \mathrm{Mhz}$. It connects with any open, WEP and WPA/WPA2 network. So it doesn't require separate network and to connect internet. Using Arduino to program the ESP 01 module for connection and working data speed rate. The hyper terminal is used to for seeing the background running process in Microcontroller. Which enabled by the wireless ZigBee transceiver to see in pc. Both the sensor is reading in the Analog form. The information is send to the Microcontroller ADC pins. Which converts the analog information signal into a Discrete form at a noted value. The is converting the physical phenomena into electrical signal through the potentiometer. The 16x2 LCD display, four data pins are connected to the microcontroller to show the output in display. These process are happening in the Real-time.[11-16] 


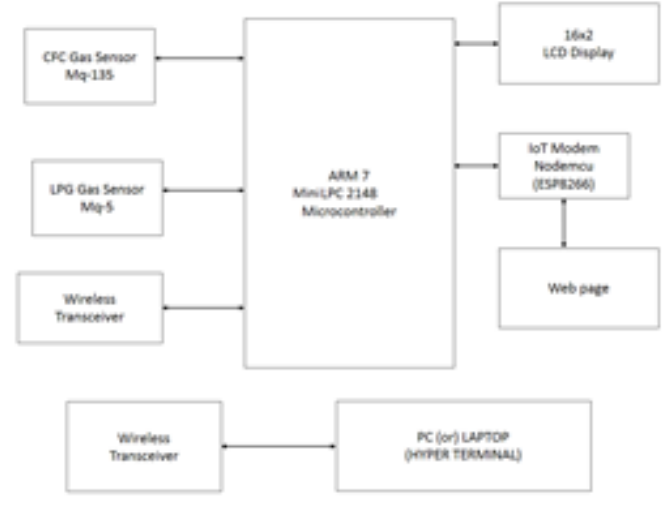

Fig. 1 Block diagram

\section{A.ARM 7 MINI LPC 2146}

ARM family is a instruction set architecture for Processors based ona a reduced instruction set computing (RISC) architecture developed by British company ARM holding. The ARM architecture is 32bit basically designed for mobile devices. It is made by Philips and it is pre-loaded with amny inbuilt peripherals making it more efficient and a reliable choice for the startup as well as high with independent power and dedicated thirty two kilocycle clock input. USB 2.0 full speed compliant device controller woth $2 \mathrm{~Kb}$ of RAM. In addition, the Mini LPC 2148 provides two buttons for reset and ISP (in system programming) and on board voltage $3.3 \mathrm{v}$ with 800 mah current. Single power supply of $12 \mathrm{v}$ Direct current or Alternative current required with power supply filtering capacitor. The crystal speed is $12 \mathrm{Mhz}$. The mini LPC 2148 have CAN chips. In addition, low power consumption, 32-bit timer and 46 GPIO pins with up to 9 external interrput pins. The mini LPC 2148 is intended with Philips (NXP semiconductor) with extra in-built features and periphals. Due to this make will make more reliable and saving for application developer. It takes 1 milli seconds to program 256 bytes and 400 milli seconds to erasing the data in full chip. [17-18]

\section{B.Gas sensor (MQ-5)}

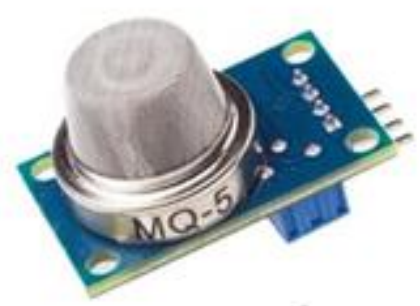

Fig. 2 MQ 5 gas module

Gas sensor (MQ5) module is beneficial for gas leakage detecting in house and business. It can also detect other harmful gases. Based on its fast response time. Measurements can be taken as soon as possible. Also the sensitivity can turn it in adjusted by the potentiometer. Sensitivity can be regulated by rotating the potentiometer.[20]

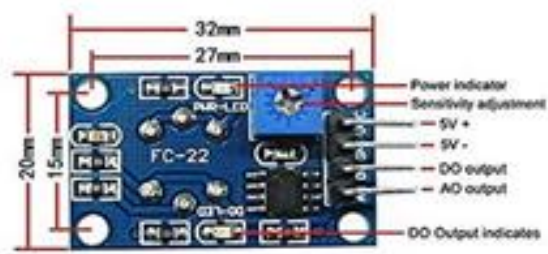

Fig 3 Pin details and architecure of MQ 5

Features:-

- Wide detecting scope.

- Stable and long life.

- Fast response and High sensitivity.

C.GAS SENSOR (MQ-135)

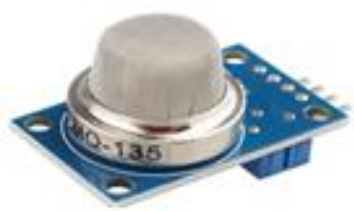

Fig.4 module of MQ 135

MQ 135 is a gas sensor and sensitive material with lower connectivity in air. When the gas increased more than the minimum level. The sensor's conductivity will also increased along with the gas concentration rising. Please use simple electrocircuit, convert change of conductivity to correspond signal of gas concentration

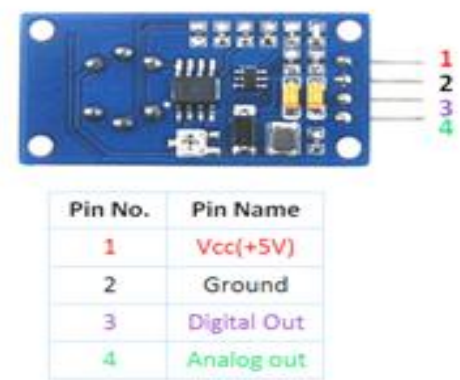

Fig. 5 pin details of MQ 135 gas sensor

The enveloped MQ135 has 4 pins. MQ135 gas sensor has other sensitivity to monitor NH3, S2- and Benzene steam, also sensitive to smoke and other harmful gases. It's low cost and applicable for different application. Sensor composed by micro AL203 ceramic tube, Tin Dioxide (SnO2) sensitive layer, measuring electrode and heater are fixed into a crust made by plastic and stainless steel net. The heater provides necessary work conditions for work of sensitive module.

\section{D.IoT MODEM (ESP 01)}

The ESP 01 is a wifi module which enables internet access in the microcontroller. It is a self-contained chip (SOC). So it doesn't need to any microcontroller to manipulate the inputs and outputs commonly. ESP 01 perform as small computer. It has 8-pins. This makes as multipurpose even cost is cheaper. The ESP 01 is operating in AP mode. Through this we can connect the device with our home wifi network. If it connected to network it works in two way communication. They were three types of modes, namely

- Access Point (AP)

- Station (STA)

- Both

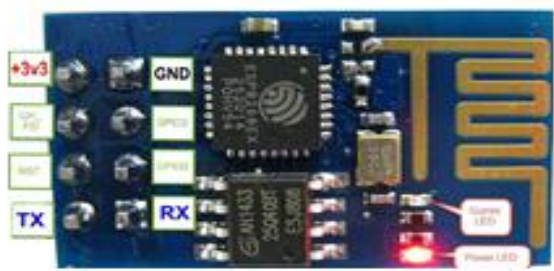

Fig 6 Pin details of ESP 01

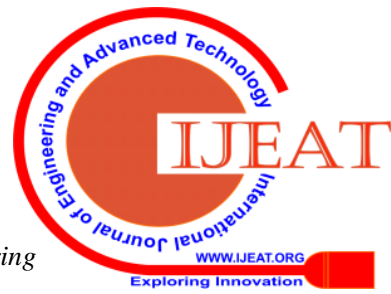


Due to AP mode we can't access our social media's only used to communicate the information to the internet. It has Integrated Chip to speed up the performance and reduce the memory requirements for some application. Only device with boots directly from the external flash.[21]

\section{Table 1 Pin details of ESP 01}

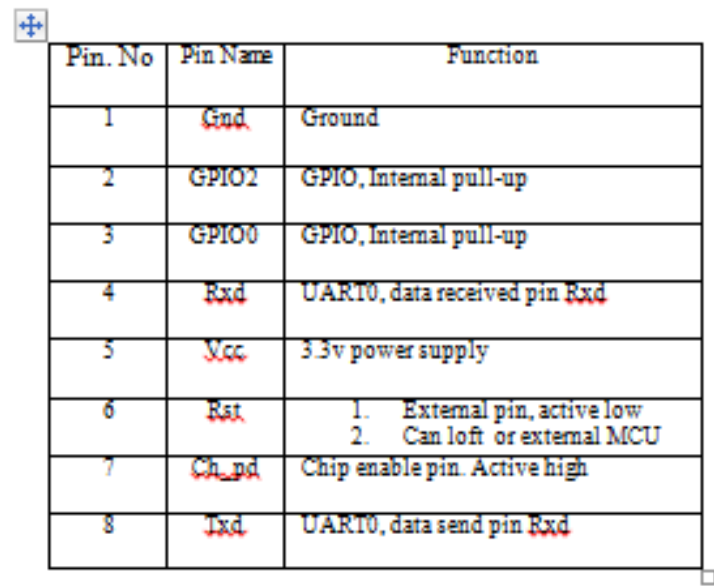

\section{E.WI-FI ZIGBEE (RFX240)}

The RFX240 is optimized device used for fully functionally of transmit power to plug and use without wire in the range of 100 meters. It's under IEEE $802.11 \mathrm{~b} / \mathrm{g} / \mathrm{n}$ application in the $2.4 \mathrm{Ghz}$ frequency range. It provides $30 \mathrm{~dB}$ gain upto $+26 \mathrm{dBm}$ linear output power with low EVM of $<3 \%$ for $802.11 \mathrm{n}$. Requires only $5 \mathrm{v}$ dc supply to operate. Complementary Metal Oxide Semiconductor (CMOS) logical control and on-chip input impedance matching and integrated RF (Radio Frequency) decoupling for the power supply
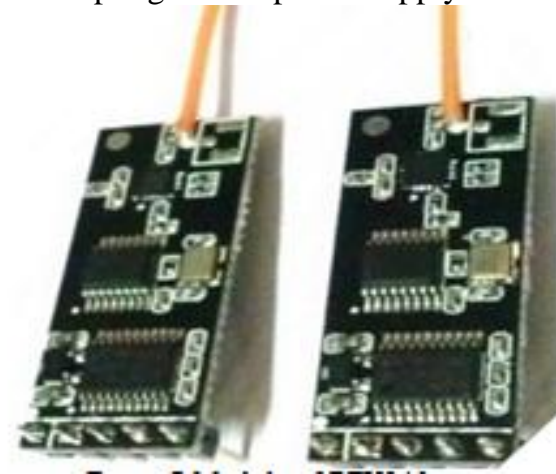

Fig. 7 Module of RFX240

\section{CHLORODIFLUOROMETHANE}

It's otherwise called as difluoromonochloromethane is better known as HCFC-22. It is colorless gas and used for the propellant and refrigerant. It has GWP, although global is using continuously to increase because of high demand in developing countries. Even it is a low ozone depletion potential of 0.055 . However, even the low ozone depletion potential is no longer considered acceptable. Because of the large consumption of the product.[20]

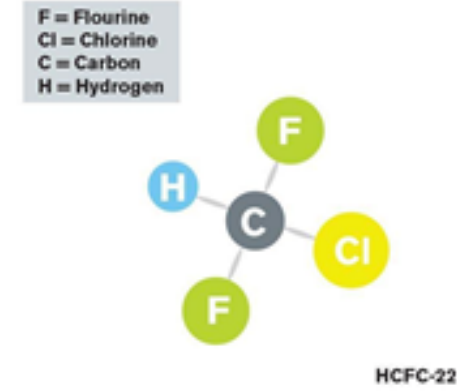

Fig 8 gas molecule of $\mathrm{HCFC}-22$

However, on January 1,2015, even though this gas is ban by government but it is still using in refrigeration equipment. By 2030, no production or import of any HCFCs will be allowed for the Environment. Most of the refrigerant contain HCFC-22 gas for the cooling content. Normally the cost of the gas is expensive and if any leakage is there the gas will spread and damage the atmosphere. India has launched the phase-out for the harmful refrigerants. Ultimate goal of the India is to end use of harmful ozone-depleting substances. The plan is meant for the 2017-2023, the goal is to phase out consumption and manufacturing of ozone-depleting and refrigerant under plan by 2030 . The HCFC is currently using in many section including refrigeration, Ac and foam manufacturing. Over 190 countries are agreed under Montreal Protocol to phase out the ODS in a time-bound manner. Under the Protocol, India has already successfully phased out the HCFC in a gradual manner.[22]

\section{FINDING AND RESULTS}

- The figure 9 shows the background running process behind the Microcontroller and LCD display held in the hyperterminal.[19]

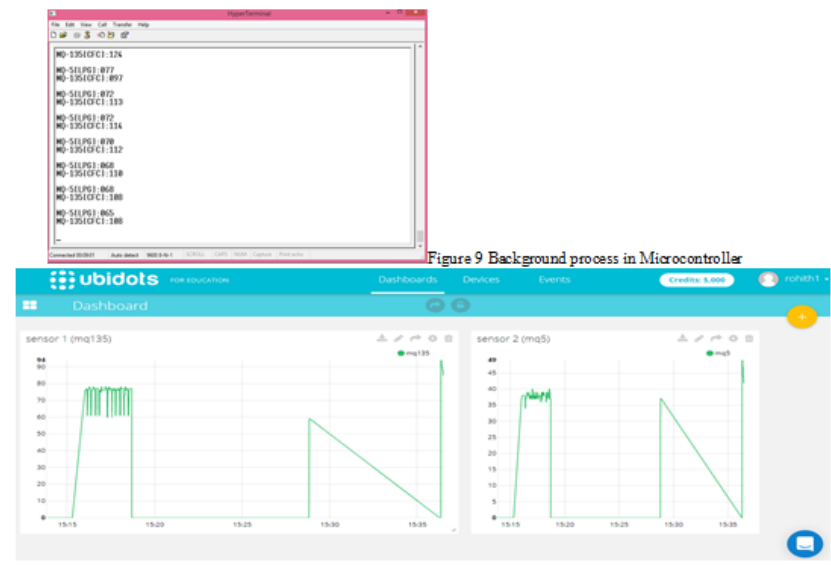

- The experiment is held in the closed room release gases for short period and continuously transmit the information data to the server wirelessly by the wifi Iot module and stored in clouds. Figure 10 Graph of HCFC-22 \& LPG gas, concertation of level of gas vs. Time and continuously reading and displayed and recorded (ubidots for education) in the clouds.

- These readings are stored and useful to the further process for the Environment in larger sector.

- The project is to monitor these gases in the home environment releases by the Air-controller and refrigerator.

Figure 10 Graph of HCFC-22 \& LPG gas, concertation of level of gas vs. Time and continuously reading and 
displayed and recorded (ubidots for education) in the cloud

\section{CONCLUSION}

Nowadays, the harmful effects of the gases used in the experiments is incrementing and is very soon taking a worst face. In this experiment through monitoring in these gases (HCFC-22 \& LPG) in a closed environment we are diagrammatically representing its adverse effects to the atmosphere (to global warming as the result of ozone layer depletion). So as a result we can get large view of a broader picture on its adverse effects on environment. Hence we can get to know the threshold limit of using these gases. As a future scope we can use this result as the means of monitoring in these gases in any other environment. In the sensor used can be further added software and components so it can be developed to monitor two or more gases simultaneously

\section{REFERENCES}

1. Kongkham, D. \& Sundararajan, M. 2019, "Distributed wideband sensing method for faded dynamic spectrum access", International Journal of Innovative Technology and Exploring Engineering, vol. 8, no. 10 , pp. 4309-4312.

2. Balaji, S., John Paul Praveen, A. \& Mohanraj, R. 2019, "Recognizable proof and analysis of palm print in biometric authentication system using bayes techniques", International Journal of Innovative Technology and Exploring Engineering, vol. 8, no. 9 Special Issue 3, pp. 1126-1129.

3. Kavitha, G., Priya, N., Velvizhi, R. \& Allin Geo, A.V. 2019, "Parallel computation in correspondence and signal processing", International Journal of Innovative Technology and Exploring Engineering, vol. 8, no. 9 Special Issue 3, pp. 1136-1139.

4. Hema, R., Sundararajan, M. \& Balaji, S. 2019, "Smartphone control robot with automatic firing gun", International Journal of Innovative Technology and Exploring Engineering, vol. 8, no. 9 Special Issue 3, pp. 625-627.

5. Kaliyamurthie, K.P., Sundar Raj, B., Velvizhi, R. \& Shanmugapriya, K. 2019, "Dual band paper substrate CPW antenna for wireless applications", International Journal of Innovative Technology and Exploring Engineering, vol. 8, no. 9 Special Issue 3, pp. 605-608.

6. Geo, A.V.A., Arunachalam, A.R., Michael, G. \& Elankavi, R. 2019, "Evaluating architecture using compact modalities", International Journal of Innovative Technology and Exploring Engineering, vol. 8, no. 9 Special Issue 3, pp. 836-838.

7. Theivasigamani, S., Jeyapriya, D. \& Anita Davamani, K. 2019, "Anamoly analyzing and exploring for wireless sensor networks", International Journal of Innovative Technology and Exploring Engineering, vol. 8, no. 9 Special Issue 3, pp. 1116-1118.

8. Jeyapriya, D., Theivasigamani, S., Velvizhi, R. \& Nandhini, P. 2019, "Program detection in wireless feeler networks", International Journal of Innovative Technology and Exploring Engineering, vol. 8, no. 9 Special Issue 3, pp. 1194-1195.

9. Gowri Sankaran, B., Karthik, B. \& Vijayaragavan, S.P. 2019, "Image compression utilizing wavelet transform", International Journal of Innovative Technology and Exploring Engineering, vol. 8, no. 10, pp. 4305-4308.

10. Gowri Sankaran, B., Karthik, B. \& Vijayaragavan, S.P. 2019, "Weight ward change region plummeting change for square based image huffman coding", International Journal of Innovative Technology and Exploring Engineering, vol. 8, no. 10, pp. 4313-4316.

11. Hema, R., Sundararajan, M. \& Balaji, S. 2019, "Smartphone control robot with automatic firing gun", International Journal of Innovative Technology and Exploring Engineering, vol. 8, no. 9 Special Issue 3, pp. 625-627.

12. Rangaswamy, K. \& Rajabhushanam, C. 2019, "Congestion control in wireless network using TCP friendly rate control (TFRC)", International Journal of Recent Technology and Engineering, vol. 8, no. 2 Special issue 3, pp. 1598-1602.

13. Tamil Selvan, S. \& Sundararajan, M. 2019, "Performance Parameters of 3 Value 8t Cntfet Based Sram Cell Design Using H-Spice", International Journal of Recent Technology and Engineering, vol. 8, no. 2 Special issue 5, pp. 22-27.
14. Vinoth, V.V. \& Kanniga, E. 2019, "Steganographical techniques in hiding text images - system", International Journal of Recent Technology and Engineering, vol. 8, no. 2, pp. 6535-6537.

15. Saravana, S., Balaji, S., Arulselvi, S. \& John Paul Praveen, A. 2019 "Reliable power quality monitoring and protection system", International Journal of Innovative Technology and Exploring Engineering, vol. 8, no. 9 Special Issue 3, pp. 644-645.

16. Sundaramoorthy, A. \& John Wiselin, M.C. 2019, "Single patch antenna with multiple feed", International Journal of Innovative Technology and Exploring Engineering, vol. 8, no. 9, pp. 1743-1747.

17. Velavan, R., Bharanidharan, S. \& Sheeba, B. 2019, "EMF pollution Causes, effects and protection", International Journal of Innovative Technology and Exploring Engineering, vol. 8, no. 9 Special Issue 3, pp. 1166-1168.

18. Veer, R.A., Arulselvi, S. \& Karthik, B. 2019, "Construction of ensemble square classification approaches in MIMO OFDM", International Journal of Engineering and Advanced Technology, vol. 8, no. 5, pp. 2039-2041.

19. Agitha, W. \& Kaliyamurthie, K.P. 2019, "Improved energy efficient in WBAN using MAC with cloud computing", International Journal of Innovative Technology and Exploring Engineering, vol. 8, no. 8, pp. 2405-2408.

20. Kastro, G.G. \& Wiselin, M.C.J. 2019, "Design and analysis of stub loaded resonator", International Journal of Recent Technology and Engineering, vol. 8, no. 1 Special Issue4, pp. 272-283.

\section{AUTHORS PROFILE}

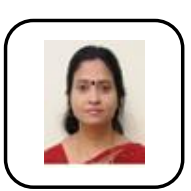

Hema $\mathbf{R}$ Assistant Professor,Department of Electronics And Communication Engineering,, Bharath Institute of Higher Education and Research, Chennai, India

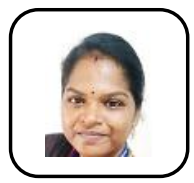

Subbulakshmi.K, Assistant Professor,Department of Electronics And Communication Engineering,, Bharath Institute of Higher Education and Research, Chennai, Indiap.

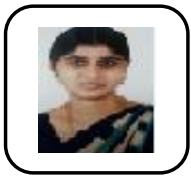

Arulselvi S.., Assistant Professor,Department of Electronics And Communication Engineering, Bharath Institute of Higher Education and Research, Chennai, India. 